\title{
Housing, inequality and a property-owning democracy in London
}

\author{
Michelle Hegarty
}

Over 30 years after Margaret Thatcher's radical reformist agenda set out to create a property-owning democracy in Britain, the majority of politicians, both on the left and right, have agreed that owning one's home is a good thing. The principles underlying this agenda have been to encourage pride, responsibility and independence amongst citizens. The political philosopher John Rawls considers that the aim of such a system is to realise the idea of society as a fair system of cooperation between citizens, who are regarded as free and equal. As the access to the ownership of property in London declines for those on middle and low incomes, what will the impact be upon these ideals, and in turn policy making, democracy and governance in London by 2062 ?

Home ownership in London is in decline. The National Housing Federation forecasts that in London the majority of people will rent by 2021 , with the number of owner-occupiers falling to $44 \%$ by 2021 . 2011Census data shows that the owner occupation rate in London has fallen from $58.9 \%$ in 2001 to $49.5 \%$ in 2011 (ONS, 2012). The National Housing Federation publication 'Home Truths 2012: London' shows that the average property in London costs $£ 421,395$ and the average annual London income is $£ 26,962$. This makes the average London house price almost 16 times the average London income (National Housing Federation, 2012).

The majority of politicians are keen to focus on the flaws in a housing market where property values are rising at an incomparable rate to earnings and leading leads to boom and bust cycles. But what politicians also recognise is the psychological importance to the British middle classes of the ownership of an asset that will appreciate over time, providing them with a pension, options for care in old age and a 'nest egg' for their children. Young people, the next generation, in London still aspire to home ownership, they aspire to escape poverty in old age and help their children despite how unrealistic, or expensive, that may feel to them.

The policy response to spiralling house prices, from left and right leaning Governments, thus far has been to attempt to alleviate pricing pressures by promoting the supply of new housing. Despite this, the demand for home ownership in London continues to outstrip the pace of supply.

How to cite this book chapter:

Hegarty, M. 2013. Housing, inequality and a property-owning democracy in London. In: Bell, S and Paskins, J. (eds.) Imagining the Future City: London 2062. Pp. 137-138. London: Ubiquity Press. DOI: http://dx.doi.org/10.5334/bag.t 
For the past 5 years, since the 'credit crunch' of 2007/2008, potential for a significant increase in house building in the near future has been seriously undermined. This is due to a lack of access to finance, for both developers and would be purchasers. While many will consider a more riskaverse approach to lending will go some way to slowing the pace of price rises, it does little to support new supply. In addition, the commitment to reducing the deficit from both main political parties suggests that any large-scale public sector investment in house building is unlikely anytime soon. The crisis in the financial markets has meant that securing finance to buy a home has become increasingly difficult. The impact has been felt strongly amongst those on low to moderate incomes who may be able to repay mortgages, but are unable to save the money needed for the high levels of deposit which lenders require.

Policies and programmes to assist first time home buyers are considered by many of those priced out of the housing market as unfair, as they can only help the chosen few. In fact some argue it only serves to keep prices inflated. Interference by the state in the housing market can be seen as the solution, or the problem, depending one's perspective. John Rawls suggests that in order for a property-owning democracy to thrive, institutions must, from the outset, put in the hands of citizens generally, and not only of a few, sufficient productive means for them to be fully cooperating members of a society on a footing of equality.

Recent history has suggested that few politicians are willing to contemplate policies that seek to reduce the prospect for the accumulation of wealth through property ownership, be that for homeowners or speculators and investors. Currently the majority of households in the UK are indeed homeowners and any such action may not be the most sensible thing to do for any politician seeking election to office.

But what happens when the balance of homeownership tips? The shifting picture of London from a majority of owner-occupiers to a minority, with the former locked out of the benefits of owning an asset, is likely to lead Londoners to look to their political leaders for a response on this issue, possibly ahead of other regions in the country. The policy response may be to encourage an increase in supply, reduction in demand through other housing options or to discourage the speculation on housing values in London.

Whatever the response needed, the more pertinent question may well be around the adequacy of the autonomy and power of London's political governance arrangements to respond effectively. The Mayor of London has recently expressed support for further measures of devolution to London recommended in a report (London Finance Commission, 2012) including all property taxes, including setting the rates of and being in control of all revenues from the full suite of property taxes. Such measures would enable London government further intervention in the housing market.

There are many who claim that the property-owning democracy ideal has achieved neither its social nor its financial goals, especially in London. Come 2062 will London be the first to see the death of the property-owning democracy or will politicians implement policy to stabilise the housing market.

\section{References}

London Finance Commission. 2012. Raising the Capital. London: London Finance Commission National Housing Federation. 2012. Home Truths 2012: London. London: National Housing Federation

ONS. 2012 (11 December). Key statistics for local authorities in England and Wales Available from http://www.ons.gov.uk/ons/rel/census/2011-census/key-statistics-for-local-authorities-inengland-and-wales/index.html. [Accessed 12 August 2013] 